\title{
The naturalisation of settler colonialism by a flowered Irish quilt in Upper Canada
}

VANESSA NICHOLAS

York University, Toronto

\section{Abstract}

Studying an embroidered quilt that Mary Morris (1811-97) made as a young girl in Ireland four years before she transported it to Upper Canada in 1829, this article argues that the floral decorative traditions imported by British women to British North America had a political dimension. The quilt, which is a patchwork of printed cottons surrounding panels of white cotton embroidered with representations of flowers, birds, insects and hunting scenes, combines embroidered motifs inspired by Indian chintz textiles with printed cotton fabrics of English manufacture featuring floral designs. As such, Morris' flowered quilt represents the imperial economy that enabled settler colonialism in Canada. This is significant because it suggests that the seemingly mild-mannered domestic objects prized or made by British women in Upper Canada contributed to a visual and material culture that was invested in destabilising the environmental and cultural sustainability of Indigenous life.

Keywords: homecraft, textiles, environmental art history, Canada, Ontario

I recognise that many Indigenous nations have long-standing relationships with the territories upon which I live and work. The area known as Tkaronto has been in the care of the Anishinabek Nation, the Haudenosaunee Confederacy, the HuronWendat, and the Métis. It is now home to many Indigenous peoples. I acknowledge the current treaty holders, the Mississaugas of the Credit First Nation. This territory is subject of the Dish with One Spoon Wampum Belt Covenant, an agreement to peaceably share and care for the Great Lakes region.

In Canada, it is customary to begin meetings, gatherings, public events and ceremonies with a territorial or land acknowledgement, which involves recognising the Indigenous peoples who were the traditional stewards and residents of the land on which you stand as well as the Indigenous peoples that inhabit the territory today. I open this article with an acknowledgement of my position as a white woman living in Toronto (Ontario, Canada) in part because my case study is concerned with how the visual and material cultures that were transplanted by British newcomers to Upper Canada in the nineteenth century helped to naturalise settler 
colonial attitudes towards the land just north of the Great Lakes and St Lawrence river. ${ }^{1}$ During the period of British settlement in this region, which began in the late eighteenth century, Indigenous and Western European artists affirmed their connection to the land in incommensurable terms. ${ }^{2}$ In the words of the art historian Jolene Rickard, who belongs to the Tuscarora Nation:

from an Indigenous perspective, the genre of landscape painting is one of the conceptual and visceral tools of colonization. If landscape paintings mark a nation's relationship to place, I argue that the Indigenous peoples of the Americas have the deepest understanding of this space, as molded in clay, carved in stone, stitched in animal hides, woven in fibres, etched on our bodies and embedded in the environmental as mounds or medicine wheels. ${ }^{3}$

Studying an embroidered quilt that Mary Morris (1811-97) made in Ireland four years before transporting it to Upper Canada in 1829 (Figure 1), this article argues that the decorative traditions imported to British North America by British women were as complicit in the project of settler colonialism as the landscape painting tradition insofar as their motifs and materials are infused with narratives of power and empire.

Initially, recent revisionist critiques of historical landscape painting in North America gave me reason to wonder whether Morris' quilt presents a more equitable and ecological view of the natural world. For example, while her quilt depicts natural subjects, particularly flowers and animals, it does not make use of perspectival space or horizon lines, artistic devices that arguably produce the illusion of an open expanse that one cannot help but imagine occupying. ${ }^{4}$ We might therefore regard the quilt's formal properties as incompatible with settler colonialism, which describes the dislocation of Indigenous peoples from their traditional territory by a considerable number of foreigners who claim the land as their own. ${ }^{5}$ Nevertheless, my research leads me to conclude that Morris' quilt befits settler colonialism because its exotic floral embroideries and printed cotton fabrics make clear references to the British Empire and its industrial strength. Citing the history of Indian chintz in British consumer culture and its eventual reproduction by British manufacturers at the beginning of the nineteenth century, I argue that Morris' quilt contains global material histories that had real implications for the environmental and cultural

\footnotetext{
1 The Province of Ontario has previously been referred to as Upper Canada (1791-1841) and Canada West (1841-67).

2 Nicholas Thomas, Possessions: Indigenous Art, Colonial Culture (New York: Thames and Hudson, 1999), 14.

3 Jolene Rickard, 'Arts of Dispossession', in Picturing the Americas: Landscape Painting from Tierra del Fuego to the Arctic, ed. Peter John Brownlee, Valeria Piccoli and Georgina Uhlyarik (New Haven, CT: Yale University Press, 2015), 115.

4 Rebecca Solnit, “Every Corner is Alive": Eliot Porter as an Environmentalist and Artist', in A Keener Perception: Ecocritical Studies in American Art History, ed. Alan C. Braddock and Christoph Irmscher (Tuscaloosa, AL: University of Alabama Press, 2009), 226.

5 Thomas, Possessions, 9.
} 
landscapes in south-eastern Ontario. I do not attribute mal-intent to Morris, and I do not draw conclusions about her interior life. Rather, I regard her quilt in relation to its global context and understand her artistic references in relation to British imperialism. In so doing, I put forth the possibility that the floral decorations favoured by British women in Upper Canada aestheticised British efforts to supplant indigeneity.

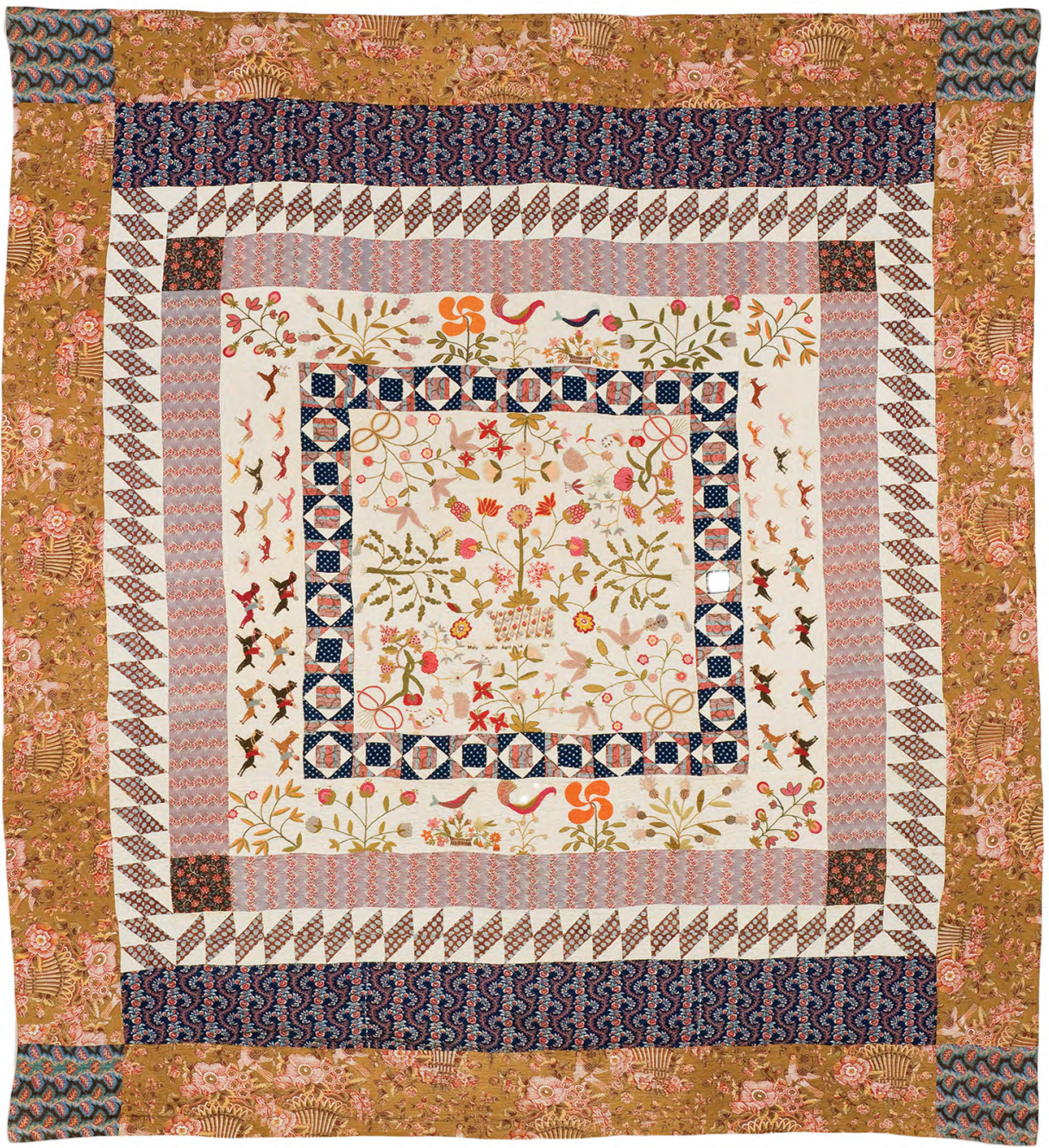

Figure 1: Mary Morris, quilt (1825), cotton and linen, $200 \times 185 \mathrm{~cm}$.

Source: Canadian Museum of History, 79-237, IMG2009-0063-0131-Dm. 
Not much is known about Morris, whose embroidered quilt is now a distinctive object in the Canadian Museum of History. Her quilt was previously owned by the Canadian historian Ruth McKendry, and it figures in a number of her publications. ${ }^{6}$ McKendry describes Morris as a skilled needlewoman born with a physical handicap that prevented her from walking, and she hazards that Morris made the coverlet shortly after arriving in British North America. ${ }^{7}$ McKendry does not specify where Morris came from. More details of Morris' biography can be found in Susan Warren's history of South Crosby (1997), a township in Ontario's historical Leeds County. ${ }^{8}$ Warren makes mention of Morris and her 'exquisite' quilt. ${ }^{9}$ According to Warren, Morris settled with her widowed mother, Mary Morris (1775-1867), and her brother, Thomas Morris (1809-93) on Lot 6, Concession 4 in South Crosby in 1829, a full four years after she signed and dated her completed quilt: 'Mary Morris Aged $141825^{\prime} .{ }^{10}$ Presuming that the Morris family migrated directly to Leeds County, the quilt must have been completed before they left for British North America. Morris' mother's monument at the St John Anglican Cemetery in Lyndhurst, Ontario, is inscribed with her birthplace, County Carlow, Ireland, and it is safe to assume that this is where Morris finished her quilt as a young teenager in 1825. Given their date of arrival in Leeds County, we can contextualise the Morris family within the last in a wave of Anglo-Irish Protestants from southeastern Ireland to settle in south-eastern Ontario between 1816 and $1833 .{ }^{11}$ This demographic gravitated towards the available if challenging terrain in and around Leeds County in part because approximately 15 Protestant families from Counties Wexford and Wicklow had settled in the area between 1809 and $1811 .{ }^{12}$

Morris' quilt would have been amongst the few personal effects that her family brought to Upper Canada. Given the level of detail in this quilt and the fact that Morris made it as a young teenager, it was likely to have been intended for her trousseau. The exceptional condition of the quilt may be attributed to the fact that Morris never married, continuing to live on her family's homestead with her brother,

\footnotetext{
6 Ruth McKendry, Quilts and Other Bedcoverings in the Canadian Tradition (Toronto: Van Nostrand Reinhold, 1979), 132; Ruth McKendry, Classic Quilts (Toronto: Key Porter Books, 1997), 26-7; Ruth McKendry, 'The Use of Embroidery on Quilts in Canada', Embroidery Canada 8, no. 2 (February 1981): 10-11.

7 McKendry, Quilts and Other Bedcoverings, 132; McKendry, Classic Quilts, 26-7.

8 Leeds County (1792-1850) is now part of Leeds and Grenville United Counties.

9 Susan Warren, Hub of the Rideau: A History of South Crosby Township (Township of South Crosby: Local Architectural Conservation Advisory Committee, 1997), 236.

10 Warren, Hub of the Rideau, 236.

11 Donald Harman Akenson, The Irish in Ontario: A Study in Rural History (Montreal and Kingston: McGillQueen's University Press, 1984), 139; Warren, Hub of the Rideau, 301.

12 Akenson, The Irish in Ontario, 49; Lucille H. Campey, Ontario and Quebec's Irish Pioneers: Farmers, Labourers, and Lumberjacks (Toronto: Dundern Press, 2018),104; Glen J. Lockwood, The Rear of Leeds and Lansdowne: The Making of Community on the Gananoque River Frontier, 1796-1996 (Lyndhurst: Corporation of the Township of Rear of Leeds and Lansdowne, 1996), 130.
} 
his wife and their children until she died at the age of $85 .{ }^{13}$ It is most likely that the quilt remained stored, though Morris may have used it gently as a decorative coverlet on her bed. The quilt's centrally planned design builds outward from a decorative square of white cotton, which she embroidered with a number of fanciful floral motifs using wool threads and a combination of chain, stem, seed and satin stitches. Her focal point is a potted plant flowering with four different types of blossoms, which is surrounded by a symmetrical arrangement of embroidered flowering plants, trees and floral sprays, some of which have attracted butterflies and peacocks. Morris frames her centrepiece with a thin perimeter of patchwork that is bordered by a band of white cotton featuring more of her needlework. Deer hunting parties run up its vertical sides, and flowering plants grow along its horizontal sides. Beyond this band of embroidered cotton are four concentric squares of pieced cotton. Of the nine different cotton fabrics represented in her piecework, eight are printed, and seven feature floral or vegetal designs. Morris' quilt combines embroidered motifs inspired by Indian chintz textiles with cotton fabrics of English manufacture printed with floral designs.

I speculate that this quilt was treasured as a sign of British culture and authority in the Morris family's Upper Canada home. British settlers were known to bring select sentimental luxuries with them to Upper Canada. For example, the well-known author Susanna Moodie carried her mother's blue and gold Coalport tea service across the ocean in 1832 only to have it break in a sleigh accident in the winter of 1834. ${ }^{14}$ More relevant to our case study is the fact that Moodie's sister and brotherin-law, Catharine Parr Traill and Thomas Traill, brought at least one luxury textile item with them when they moved to Upper Canada in 1832. In her autobiography, The Backwoods of Canada (1836), Traill recalls receiving Indigenous women at her homestead who wished to admire a gay chintz dressing-gown belonging to my husband'. ${ }^{15}$ Indian chintz became a popular material for men's morning gowns in Europe sometime during the third quarter of the seventeenth century and remained fashionable for men's and women's fashions alike throughout the eighteenth century. ${ }^{16}$ There is a men's banyan or informal robe made from imported Indian chintz in the Victoria and Albert Museum collection that dates to the third quarter of the eighteenth century, and it is possible that Traill's robe also dates to this period.

13 See Morris family, 1851 Census of Canada East, Canada West, New Brunswick, and Nova Scotia, Crosby, Leeds County, Canada West (Ontario), schedule A. Microfilm C-11733, p. 53, lines 18-28. Library and Archives Canada, Ottawa; Morris family, 1871 Canada Census, Crosby South, Leeds South, Ontario. Microfilm C-10001, p. 49, family no. 178. Library and Archives Canada, Ottawa; Morris family, 1881 Canada Census, Crosby South, Leeds South, Ontario. Microfilm C-13232, pp. 65-6, family no. 327. Library and Archives Canada, Ottawa; Morris family, 1891 Canada Census, Crosby South, Leeds South, Ontario, Canada. Microfilm T-6350, family no. 304. Library and Archives Canada, Ottawa; Mary Morris (d. 1897), Registrations of Deaths, 1869-1947, County of Leeds, South Crosby. MS 935, reel 84, pp. 553-4, line 4. Archives of Ontario, Toronto.

14 Charlotte Gray, Sisters in the Wilderness: The Lives of Susanna Moodie and Catherine Parr Traill (Toronto: Viking, 1999), 96.

15 Catherine Parr Traill, The Backwoods of Canada [1836] (Ottawa: Carleton University Press, 1997), 121.

16 John Irwin and Katherine Brett, Origins of Chintz (London: Her Majesty's Stationery Office, 1970), 34. 
He was born in 1793, making it conceivable that he was in possession of a banyan owned by his father. ${ }^{17}$ According to his wife, her Indigenous neighbours petitioned her to sell or trade the dressing gown, but she 'resolutely refused to part with it'. In addition to their association with home and family, tea services, chintz robes and embroidered quilts would have been valued as signifiers of British culture in an unfamiliar, harsh landscape.

This is significant because it suggests that the seemingly mild-mannered domestic objects prized or made by British women in Upper Canada contributed to a visual and material culture that was invested in undermining Indigenous environmental and cultural sustainability. Understanding the insidious dimension assumed by Morris' quilt in the Canadian context requires that we further establish the discord between the understandings of land and nature held by Indigenous and European settler societies in North America's north-east during the eighteenth and nineteenth centuries. The Dish with One Spoon Wampum Belt Covenant that I cited in my land acknowledgement above refers to a peace agreement made in 1701 between the Anishinaabeg and Haudenosaunee First Nations within the St Lawrence River valley and Great Lakes region that exemplifies the distinctively Indigenous outlook on territory and resources. The arrival of Europeans in this region in the seventeenth century produced an intensified fur trade that led to nearly a century of conflicts between Anishinaabeg and Haudenosaunee residents over access to hunting grounds. ${ }^{18}$ In the summer of 1701 , approximately 1,000 delegates representing more than 30 First Nations from across the St Lawrence River valley and Great Lakes regions met in Montreal to ratify the peace treaty predicated on a metaphor that had long been used by those present to describe agreements concerning shared hunting grounds, the dish with one spoon. ${ }^{19}$ According to the Indigenous scholar Hayden King, who belongs to the Beausoleil Nation:

this pragmatic arrangement recognized that even as distinct nations, we can share the same territory. But we need to acknowledge our mutual obligations to ensure the dish is always full ... there are no forks or knives at the table with which we can stab each other, just a spoon that we share. ${ }^{20}$

17 Gray, Sisters in the Wilderness, 45; Parakunnel J. Thomas, 'The Beginnings of Calico-Printing in England', English Historical Review 39, no. 154 (April 1924): 215, doi.org/10.1093/ehr/XXXIX.CLIV.206.

18 Victor P. Lytwyn, 'A Dish with One Spoon: The Shared Hunting Grounds Agreement in the Great Lakes and St. Lawrence Valley Region', in Papers of the 28th Algonquian Conference, ed. David H. Pentland (Winnipeg: University of Manitoba, 1997), 211.

19 Lytwyn, 'A Dish with One Spoon', 210, 217.

20 Hayden King, 'First Nations Crisis is About Land. We Need a New Settlement', The Globe and Mail, 10 February 2015, accessed 20 January 2020. 
This communal understanding of land and resource management is represented in Indigenous artistic traditions, which tend to centre the body in a cosmology of vertical space and circular time that binds all living and non-living things. ${ }^{21}$ Take, for example, the edge of a beaded skirt produced and worn in the mid-nineteenth century by Caroline G. Parker (1826-92), who belonged to the Tonawanda Band of the Seneca Nation within the Haudenosaunee Confederacy. In her contribution to the exhibition catalogue for 'Picturing the Americas: Landscape Painting from Tierra del Fuego to the Arctic', which opened at the Art Gallery of Ontario in 2015, Rickard describes Parker's skirt as 'perhaps the single most influential example of the Haudenosaunee relationship to the earth'. ${ }^{22}$ To illustrate this claim, she stresses that the domes created by white and blue beaded lines on the inside edge of the Parker's skirt refer to a multitude of earth-based practices and beliefs. Firstly, Haudenosaunee women were traditionally the primary farmers in their communities and they planted their most important crops (corn, beans and squash) together in mounds, a sustainable cropping system known as intercropping. ${ }^{23}$ It is possible that the three ovate shapes contained within the domes or mounds on Parker's skirt represent these three crops, which were referred to as the 'three sisters'. This dome shape likely also symbolises Turtle Island, referring to a creation story common amongst many traditions within the Algonquian and Iroquoian language groups wherein the North American continent was formed on the back of a giant turtle. ${ }^{24}$ This skirt thus exemplifies the ways that Indigenous art and design were employed to maintain corporeal and cosmological ties to ancestral homelands.

According to King, settler populations were incapable of observing the Dish with One Spoon Wampum Belt Covenant: 'As settlers began to proliferate in what would become the Great Lakes area, they too were invited to eat from the dish. But over time their collective appetite eroded the principles of mutual autonomy, humility and sustainability. ${ }^{25}$

The inability of settlers to understand the codes and ethics of shared territory can be attributed to their view of land in terms of power and commerce. This understanding of territory and resources is represented by European artistic traditions, in particular the landscape genre. In her contribution to the 'Picturing the Americas' exhibition catalogue, the art historian Ruth Phillips attributes the political utility of landscape painting in nineteenth-century North America to its perspectival representation of space, which she claims corresponds with Western concepts of ownership, horizontal space and linear time. By design, then, landscape paintings were antithetical to

21 Ruth Philips, 'Overview: Indigenous Lands / Settler Landscapes: Art Histories Out of Joint', in Picturing the Americas: Landscape Painting from Tierra del Fuego to the Arctic, ed. Peter John Brownlee, Valeria Piccoli and Georgina Uhlyarik (New Haven, CT: Yale University Press, 2015), 93.

22 Rickard, 'Arts of Dispossession', 117.

23 Ibid., 118

24 Ibid.

25 King, 'First Nations Crisis is About Land'. 
traditional Indigenous relationships to land, which were informed by cosmologies that centred reciprocity, defined space vertically and observed natural cycles. ${ }^{26}$ In the same exhibition catalogue, the art historian Peter John Brownlee further stresses the role that landscape painting in the Americas played in establishing an entitlement to natural resources amongst those who held private property: 'landscape panting in the Americas glorified and helped to facilitate the extraction of natural resources in pictures that accorded with the aesthetic tastes and entrepreneurial spirit of the landowning classes'. ${ }^{27}$ Brownlee cites W. J. T. Mitchell's Landscape and Power (1994), an edited volume of essays that establishes the historical alignment of landscape painting with the economic interests of landowners. ${ }^{28}$

The critical treatment of North American landscape paintings by Phillips and Brownlee is informed by environmental art history, an emergent line of inquiry within the environmental humanities that considers how visual and material cultures represent the natural world. To date, the relatively limited scope of prominent scholarship in this field has focused on the historical landscape painting tradition. Significantly, the landscape painting tradition has a masculinist skew and an over-investment in the study of this genre by environmental art historians inevitably risks excluding women from the discourse. The American and Canadian landscape traditions, in particular, have long cast the continent's wild spaces as belonging to intrepid Western men. The art historian Marilyn McKay argues that this gender bias is especially strong in Canada, where the punishing terrain and climate were exalted for producing a rugged, virile and 'manly' national character in the decades following the confederation of the British North American colonies in $1867 .{ }^{29}$ British women in late eighteenth- and early nineteenth-century Canada duly perceived that they had a limited role to play in the cultural treatment of their natural surroundings. According to McKay, 'consciously or unconsciously, they understood that panoramas belonged to men. ${ }^{30}$ The decorative traditions of British women, however, often feature natural imagery and, in particular, florals. It thus seems fair to ask whether Morris' flowered quilt and others like it might be implicated in the same power politics that have been attributed to the masculine landscape painting tradition in the North American context.

Answering this question requires that we situate Morris' embroideries within the global context of the British Empire. Morris' embroidery designs derive in large part from Indian chintz fabrics. Today, 'chintz' is used to describe any cotton or

26 Ruth Philips, 'Overview: Indigenous Lands/Settler Landscapes, Art Histories Out of Joint', 93.

27 Peter John Brownlee, 'Overview: Land as Resource', in Picturing the Americas: Landscape Painting from Tierra del Fuego to the Arctic edited by Peter John Brownlee, Valeria Piccoli and Georgina Uhlyarik, 132-5 (New Haven: Yale University Press, 2015), 132.

28 See W. J. T. Mitchell, ed., Landscape and Power (Chicago: University of Chicago Press, 2002).

29 Marylin McKay, Picturing the Land: Narrating Territories in Canadian Landscape Art 1500-1950 (Montreal and Kingston: McGill-Queen's University Press, 2011), 159.

30 McKay, Picturing the Land, 58. 
linen fabric having a floral pattern; but historically the term referred to a cotton fabric made in India for the European market that was painted or printed with vegetal designs using mordant and resist dyes. The brilliance and fastness of their dyes made chintz fabrics novel and desirable in seventeenth-century Europe, where fabric-printing techniques were still relatively primitive. ${ }^{31}$ Indian chintz fabrics were imported to England by the East India Company as early as 1613, and their popularity rocketed in the early $1680 \mathrm{~s}^{32}$ The commercial success of Indian chintz in the British marketplace compelled parliament to protect the domestic textile industry by banning the importation of this commodity in 1701. As the supply of Indian chintz in Britain diminished, the cultural value of these fabrics and their designs increased. ${ }^{33}$ During this period, British embroiderers developed a floral iconography inspired by Indian chintz designs; however, needlework booklets with printed designs modelled after Asian floral designs were being sold in continental Europe as early as $1600 .{ }^{34}$ The influence of Indian chintz endures in Morris' quilt embroideries, which include several floral motifs that were common in Indian chintz fabrics designed for the British and French markets towards the end of the late eighteenth century, including peonies, chrysanthemums and lilies. ${ }^{35}$

According to the art historian Natasha Eaton, so-called oriental wares, including Indian chintz panels and fabrics, were initially assigned value in eighteenth-century England because they internationalised domestic interiors and thereby defined the home in relation to the British Empire. ${ }^{36}$ Similarly, the historian Joanna de Groot cites the British market for Indian cotton and cotton-based textiles to argue that common consumer goods connected average Britons to the larger British Empire from the eighteenth century onwards. She writes:

the meanings of everyday activities like dress, eating or cleaning were part of experiences and ideas of home, community, family and gender roles and differences, but also had powerful, if implicit, associations with patriotism (the use of 'empire' goods) and exotic pleasures (the glamour of familiar tropical or oriental products). ${ }^{37}$

\footnotetext{
31 Irwin and Brett, Origins of Chintz, 1.

32 Ibid., 3, 5.

33 Colleen R. Callahan, 'A Quilt and Its Pieces', Metropolitan Museum Journal 19, no. 20 (1984-85): 102, doi.org/ $10.2307 / 1512815$.

34 A Picture Book of Flowers in English Embroidery (London: Victoria and Albert Museum, 1938), n.p.; Lemuire and Riello, 906.

35 Irwin and Brett, Origins of Chintz, 20-1.

36 Natasha Eaton, 'Nostalgia for the Exotic: Creating an Imperial Art in London, 1750-1793', Eighteenth Century Studies 39, no. 2 (Winter 2006): 230, doi.org/10.1353/ecs.2005.0060.

37 Joanna de Groot, 'Metropolitan Desires and Colonial Connections: Reflections on Consumption and Empire', in At Home With the Empire: Metropolitan Culture and the Imperial World edited by Catherine Hall and Sonya O. Rose, 166-90 (Cambridge: Cambridge University Press, 2006), 170, doi.org/10.1017/CBO9780511802263.008.
} 
Groot writes as a contributor to At Home With The Empire (2006), edited by Catherine Hall and Sonya O. Rose, who themselves assert that that the nineteenth-century British notion of 'home' was 'informed by tropes of material comfort associated with food, cleanliness, etc., themselves dependent upon imperial products' ${ }^{38}$ Their view is that imperial power had by then become so omnipresent in the everyday lives of Britons, regardless of their position on the imperial agenda, that it was simply mundane. As such, while Morris' embroideries connect her to 'global circuits of production, distribution and exchange, [and] to the exploitation and oppression of millions of other imperial subjects', she may not have recognised this herself. ${ }^{39}$

Morris then inadvertently compounds the political significance of her chintzinspired embroideries by surrounding them with squares of printed cotton fabrics manufactured in England. The popularity of Indian chintz textiles incentivised British and European manufacturers to appropriate Indian craftsmanship and substitute domestic products for these imported commodities. ${ }^{40}$ As we have seen, embroiderers were amongst the first to emulate the effect of Indian chintz fabrics, adapting their floral and botanical motifs, and Morris' own embroideries are informed by this tradition. ${ }^{41}$ Economic historians speculate that the development of England and Europe's cotton printing industries were spurred by protectionist measures, including the prohibition on Indian chintz imports by British parliament in 1701. ${ }^{42}$ Plain Indian cottons called 'calicoes' were initially exempt from the sumptuary legislation, and they thereby became the ground for the English woodblock printers aspiring to replicate the effect of Indian chintz. When the consumption of all imported cotton was prohibited for a period during the first half of the eighteenth century, English calico printers adapted their practices to fustians and linens. Wooden blocks were used by calico printers until the 1750s, when copperplate printing came into use. ${ }^{43}$ Metal plates enabled the production of both considerably larger repeat units and more detailed designs than could be achieved with wooden blocks. ${ }^{44}$ The biggest innovation came in 1783 , when the Scot Thomas Bell patented roller printing, a method of printing using engraved cylinders. ${ }^{45}$ After the spinning jenny, water frame and spinning mule were invented

\footnotetext{
38 Catherine Hall and Sonya O. Rose, 'Introduction: Being at Home with the Empire', in At Home With the Empire: Metropolitan Culture and the Imperial World, ed. Catherine Hall and Sonya O. Rose, 1-31 (Cambridge: Cambridge University Press, 2006), 25, doi.org/10.1017/CBO9780511802263.001.

39 Catherine Hall and Sonya O. Rose, 'Introduction', 21.

40 Beverly Lemire and Girgio Riello, 'East and West: Textiles and Fashion in Early Modern Europe', Journal of Social History 41, no. 4 (Summer 2008): 888, doi.org/10.1353/jsh.0.0019.

41 Lemuire and Riello, 'East and West', 894.

42 Lemuire and Riello, 'East and West', 898; Thomas, 'The Beginnings of Calico-Printing in England', 208.

43 Audrey W. Douglas, 'Cotton Textiles in England: The East India Company's Attempt to Exploit Developments in Fashion 1660-1721', Journal of British Studies 18, no. 2 (May 1969): 36, doi.org/10.1086/385569; Giorgio Riello, 'Asian Knowledge and the Development of Calico Printing in Europe in the Seventeenth and Eighteenth Centuries', Journal of Global History 5 (2010): 23, doi.org/10.1017/S1740022809990313.

44 Stuart Robinson, A History of Printed Textiles (London: Studio Vista, 1969), 18.

45 Lemuire and Riello, 'East and West', 903.
} 
in the 1770 s, the English north-west quickly transformed into a profitable cottonmanufacturing centre, and by 1820 the bulk of England's calico printers could be found near the cotton mills in Lancashire and Carlisle. ${ }^{46}$

Printed cottons were thus seen to represent Britain's ingenuity and its new industrial capabilities, further establishing its confidence as a global power. Having finally produced a domestic product that rivalled Indian chintz, the British increasingly differentiated themselves from the Indians by their command of mechanical manufacturing. ${ }^{47}$ The sheer productivity of roller printing, for example, was thrown into stark relief when compared to the process of an Indian craftsman, who typically took two weeks to paint a roll of calico 7 metres long. ${ }^{48}$ According to the historian Michelle Maskiell, such comparisons strategically cast 'contemporary Indian handicrafts [as] living antiques, in the sense that they were products of a civilization that was itself considered antique'. ${ }^{49}$ By the second half of the nineteenth century, industrial exhibitions like the Great Exhibition (1851) at the Crystal Palace in London's Hyde Park duly attributed the great political and economic power of the British Empire to its ability to appropriate and improve upon design and decorative traditions from its colonies using domestic manufacturing. By extension, the British Government actively endorsed British textiles over all Indian ones. This is further seen in the promotion of the woven shawls manufactured in Paisley, Scotland, over Kashmiri shawls by British officials. For example, Queen Victoria often appeared publicly in Paisley shawls though she gave Kashmiri shawls to her ladies-in-waiting. ${ }^{50}$ In the early twentieth century, Indian nationalists encouraged the revival of indigenous textile traditions. India's handicraft revivalist movement protested against the obliteration of India's textile industry by the rise of British manufacturing and its effect on worldwide tastes, and it further sought to recover India's textile traditions from their entanglement with British colonial interests. ${ }^{51}$

Morris collapses this material history into her quilt by combining Indian chintz imagery in her embroideries with some of the earliest machine-printed cottons of English manufacture. The bulk of the fabrics in Morris' quilt feature small-scale floral prints that were most likely produced using roller printers, which were widely adopted by English textile manufacturers after $1815 .{ }^{52}$ The size of the rollers limited their capacity to tell visual stories, and designers thus turned to decorative motifs

\footnotetext{
46 Robinson, 'A History of Printed Textiles', 18.

47 Lemuire and Riello, 'East and West', 900.

48 Ibid., 903.

49 Michelle Maskiell, 'Consuming Kashmir: Shawls and Empires, 1500-2000', Journal of World History 13, no. 1 (Spring 2002): 41, doi.org/10.1353/jwh.2002.0019.

50 Maskiell, 'Consuming Kashmir', 40.

51 Maskiell, 'Consuming Kashmir', 52; Irfan Habib, 'Colonization of the Indian Economy, 1757-1900', Social Scientist 3, no. 8 (March 1975): 30, doi.org/10.2307/3516224.

52 Florence M. Montgomery, Printed Textiles: English and American Cottons and Linens, 1700-1850 (New York: Viking, 1970), 287.
} 
that required less surface area. ${ }^{53}$ According to the design historian Peter Floud, the limitations of roller printing produced new design conventions that 'consisted of patterns with the motifs arranged in continuous parallel vertical cascades' ${ }^{54}$ Geometric and abstract motifs were also introduced into the vernacular, though naturalism in the form of mossy and floral trails remained popular. ${ }^{55}$ For example, Morris' quilt incorporates four lengths of chintz featuring trails of pansies printed in red on a light blue ground. At first glance, the four printed cotton lengths at the quilt's outermost edge might be mistaken for being block-printed; however, the flowers and birds in this design are stippled. Stippling is a shading technique that is unique to engraving, so we can deduce that this cotton was printed using either an engraved copper plate or an engraved copper cylinder. ${ }^{56}$ The short vertical repeat in the cotton at the border of Morris' quilt suggests that it was produced by a copper cylinder rather than by a copper plate. ${ }^{57}$ The number of printed cottons in Morris patchwork is itself a testament to the accelerated cycle of commerce that roller-printing technology made possible. ${ }^{58}$

Though Morris made her quilt in Ireland, there is evidence that printed cotton was available for purchase in Upper Canada and would have adorned the interiors of other homesteads in the region. Cotton cloth became Britain's leading export in the early nineteenth century, and by 1795 Canada and the United States already accounted for over half of England's cotton exports, which would have included printed cotton fabrics. ${ }^{59}$ The Morris family would have been able to purchase printed cottons from the general stores in Yonge Mills and Elizabethtown. These were both owned by Charles Jones (1781-1840), who imported more than approximately 200 yards of printed cotton to sell in his stores in $1808 .{ }^{60}$ An invoice book kept by a dry goods business in Toronto during the 1840s, which is now in the Archives of Ontario, further shows that printed cotton was readily available to Upper Canadian consumers before Confederation in 1867. More than 20 of this invoice book's line items include the word chintz, a term that would have referred to printed cotton and that appears frequently in regional advertisements throughout the colonial period. Many more of the record's line items include descriptions of different types of printed

53 Wendy Hefford, 'Design for Printed Textiles in England: 1750 to 1850', in British Textiles: 1700 to the Present, ed. Linda Parry (London: V\&A Publishing, 2010), 80; Mary Schoeser and Celia Rufey. English and American Textiles from 1790 to the Present (London: Thames and Hudson, 1989), 57.

54 Peter Floud, English Printed Textiles, 1720-1836 (London: Her Majesty's Stationery Office, 1960), 6.

55 Hefford, 'Design for Printed Textiles in England', 80.

56 Hefford, 'Design for Printed Textiles in England', 80; Schoester and Rufey, English and American Textiles, 57; Montgomery, Printed Textiles, 291.

57 Copperplate designs typically have large-scale vertical repeats, measuring up to a yard high, while engraved copper cylinder designs have reduced vertical repeats that do not exceed a foot in height: Montgomery, Printed Textiles, 291.

58 Montgomery, Printed Textiles, 287.

59 Chris Aspin, The Cotton Industry [1981] (Princes Risborough: Shire, 1995), 4; Schoeser and Rufey, English and American Textiles, 29.

60 Douglas McCalla, Consumers in the Bush: Shopping in Rural Upper Canada (Montreal and Kingston: McGillQueen's University Press, 2015), 3, 48, 235. 
cotton fabrics, including 'rainbows' and 'fancies' ${ }^{61}$ There is no mention of chintz in the Registers of Manifests for goods arriving by ship at the Toronto Customs House from the United States between 1836 and $1841 .^{62}$ This seems to indicate that the bulk of Upper Canada's imported textiles came from England, even though the United States began developing its textile printing industry after the Revolutionary War. The popularity of printed cotton amongst British settlers in Upper Canada shows that the imperial tastes exhibited by Morris' quilt informed Upper Canada's consumer culture.

Painted and printed cottons also appealed to north-eastern Woodlands Indigenous people, who developed aesthetic sensibilities that favoured florals over the course of the eighteenth and nineteenth centuries. ${ }^{63}$ The acceptance of printed cotton fabrics by this demographic is documented by Isaac Weld, who wrote an account of his travels through the United States and Canadian provinces in the 1790s. On the subject of Indigenous men's dress in Upper Canada, he writes, 'when it is cool, or when they dress themselves to visit their friends, they put on a short shirt, loose at the neck and wrists, generally made of coarse figured cotton or calico of some gaudy pattern, not unlike what would be used for window or bed curtains' ${ }^{64}$ The fabrics that Weld identifies as fashionable amongst Woodlands Indigenous men during the 1790s would have been the plate-printed fustians or linens that predated the integration of English industrial cotton manufacturing and printing at the beginning of the nineteenth century. While we might reason the Indigenous peoples adopted printed fabrics and cottons out of necessity or convenience, there is evidence that they took an active interest in their floral designs. For example, we have already considered the fact that Traill briefly describes being visited by a number of Indigenous women who wished to admire her husband's chintz dressing gown. ${ }^{65}$ This passing episode in her autobiography suggests that north-eastern Woodlands Indigenous women, in particular, admired and studied the floral fabrics common in settler households.

The prevalence of printed English cotton in Upper Canada therefore derived in part from the fact that British settlers and business interests had traded these materials to purchase access to North America's natural resources and land from Indigenous peoples throughout the eighteenth and nineteenth centuries. Indeed, north-eastern Woodlands Indigenous people were likely to have obtained flowered fabrics by way of their fur trade with the Hudson's Bay Company. The British began trading with Canada's Indigenous populations in the seventeenth century through the Hudson's

61 Toronto Dry Goods Invoice Books, 1846-47. Reference F 4313. Archives of Ontario, Toronto.

62 Toronto Customs House fonds, 1836-1841. Reference MU 2991. Archives of Ontario, Toronto.

63 The Woodlands refers to the forested territory that once extended from the Atlantic coast to the Great Plains, and from Lake Superior's northern shores down to the Gulf of Mexico. Before the arrival of Europeans, this territory was populated by Indigenous communities belonging to the Algonquian, Iroquoian, Siouan and Muskogean language groups.

64 Isaac Weld, Travels through the states of North America, and the provinces of Upper and Lower Canada, during the years 1795, 1796, and 1797 (London: John Stockdale, 1799), 380.

65 Traill, The Backwoods of Canada, 121. 
Bay Company, which, like the East India Company, was established by royal charter in the seventeenth century. ${ }^{66}$ The company was primarily concerned with acquiring beaver pelts for the English hatting and felting industries from Indigenous trappers. ${ }^{67}$ In an effort to maximise the North American marketplace and avoid cultural clashes, the company relied on its traders to report what commodities were desirable to Indigenous trappers. It is conceivable that the developing taste for floral fabrics amongst north-eastern Woodlands Indigenous people resulted in a supply of printed English cottons at a number of the company's trading posts. ${ }^{68}$ Starting in the 1740s, cloth became one of the most popular commodities at the company's trading posts. ${ }^{69}$ The possibility that printed English cotton fabrics accounted for an amount of this is presented by the historian Edwin Rich, who writes that 'gay cloth of different kinds' could be procured at company trading posts during the eighteenth century. ${ }^{70}$ The important place of printed English cotton in IndigenousBritish relations illustrates the historian Maxine Berg's assertion that 'the process of inventing new consumer good to substitute for Asian luxuries was not just about connections between Europe and Asia, but included Africa and the Americas'. ${ }^{71}$

British textiles and other trade goods duly formed the basis for both co-operation and conflict between British and Indigenous populations in the Great Lakes and St Lawrence River valley regions throughout the eighteenth and nineteenth centuries. For example, at the close of the American Revolution, British authorities offered the Mississauga guns, ammunition, clothing, 12 laced hats and red cloth sufficient for 12 coats in exchange for territory stretching along the northern shores of Lake Ontario and the St Lawrence River, where they wished to resettle Loyalist refugees. ${ }^{72}$ The Crawford Purchase, which is so called because its British interests were represented by Captain William Redford Crawford, was negotiated with a number of Mississauga chiefs at a meeting on Carleton Island in Lake Ontario in October 1783. This meeting was also attended by a representative from the Mohawk at Kanesatake, Chief Mynas, who ceded a further tract of land along the upper part of the St Lawrence River south of the Ottawa River in exchange for a year's worth of clothing for his family. ${ }^{73}$ While the British authorities regarded the Crawford Purchase as a transfer of land ownership, Indigenous authorities are likely to have regarded the Crown's offerings as tributes or

\footnotetext{
66 Nick Robins, The Corporation that Changed the World (London: Pluto Press, 2012), 23.

67 Ann M. Carlos and Frank D. Lewis, 'Marketing in the Land of Hudson Bay: Indian Consumers and the Hudson's Bay Company, 1670-1770’, Enterprise \& Society 3, no. 2 (June 2002): 286, doi.org/10.1017/s14672227 00011678.

68 E. E. Rich, 'Trade Habits and Economic Motivation Among the Indians of North America', Canadian Journal of Economics and Political Science 26, no. 1 (February 1960): 49, doi.org/10.2307/138817.

69 Carlos and Lewis, 'Marketing in the Land of Hudson Bay', 302.

70 Rich, 'Trade Habits and Economic Motivation', 45.

71 Maxine Berg, 'In Pursuit of Luxury: Global History and British Consumer Goods in the Eighteenth Century', Past \& Present 182 (February 2004): 132, doi.org/10.1093/past/182.1.85.

72 Robert J. Surtees, 'Land Cessions, 1763-1830', in Aboriginal Ontario: Historical Perspectives on the First Nations, ed. Edward S. Rogers and Donald B. Smith (Toronto: Dundern Press, 1994), 102.

73 Warren, Hub of the Rideau, 4.
} 
gifts acknowledging their agreement to share the land with the dislocated people. ${ }^{74}$ British textiles were thus one of the means by which the British imposed their understanding of land as property and a resource onto Indigenous people and territories, and we must recognise that the situation of Morris and her quilt in Upper Canada was made possible by the disproportionate trade of south-eastern Ontario for lengths of cloth and other trade goods.

Significantly, then, Morris' quilt is a physical artefact of the first stages of settler colonialism in Upper Canada, meaning it arrived with outsiders who came to inhabit Indigenous land and claim it as their own on largely false pretences. Settler colonialism is distinct from what scholars Eve Tuck, Kate McCoy and Marcia McKenzie call 'exploitation colonialism', which entails:

small numbers of colonizers [going] to a new place in order to dominate a local labor force to harvest resources to send back to the metropole, for example the spice and opium trade that impelled the colonization of India by several different European empires. ${ }^{75}$

Of course, as we have seen, Morris' embroideries reference the Indian chintz fabrics that were introduced to British consumers by way of exploitation colonialism, and we might understand her quilt as an object that bridges the histories of exploitation colonialism in India with those of settler colonialism in North America. In fact, the British floral decorative traditions that had initially been inspired by India's chintz fabrics found a new home in Canada precisely because they had been so fully appropriated by the British imperial imaginary that they had become commonplace aspects of British life. As such, they contributed to a visual and material culture in early Canada that was invested in supplanting indigeneity, implicating British women and their domestic decorations in the process of settler colonialism and its dependence on the continuous disavowal of Indigenous history and rights.

According to Tuck, McCoy and McKenzie, one of the notable characteristics of settler colonialism is its 'attempt (and failure) to contain Indigenous agency and resistance'. ${ }^{76}$ Indeed, in keeping with the cultural agency that the northeastern Woodlands Indigenous people exercised by adopting English printed cotton fabrics in the eighteenth and early nineteenth centuries, they ultimately subverted the assimilationist policies and attitudes that intensified in Canada during the Victorian period by concealing sacred information in the floral beadwork that they developed in response to the floral decorative traditions imported by settlers like

74 Marijke Huitema, Brian S. Osborne and Michael Ripmeester, 'Imagining Spaces, Constructing Boundaries, Conflicting Claims: A Legacy of Postcolonial Conflict in Eastern Ontario', International Journal of Canadian Studies 25 (Spring 2002): 96.

75 Eve Tuck, Kate McCoy and Marcia McKenzie, 'Land Education: Indigenous, Post-Colonial, and Decolonizing Perspective on Place and Environmental Education Research', Environmental Education Research 20, no. 1 (2014): 6, doi.org/10.1080/13504622.2013.877708.

76 Tuck, McCoy and McKenzie, 'Land Education', 6. 
Morris. Indigenous artists in the Great Lakes and St Lawrence River valley region began incorporating florals into their quillwork and moose-hair embroidery at the beginning of the nineteenth century, and floral beadwork evolved thereafter. ${ }^{77}$ The graphic representations of the Indigenous cosmologies that had been so prominent in the region's visual and material culture prior to contact were viewed with suspicion by the British because they represented non-Christian spiritual beliefs. The development of an Indigenous floral iconography was therefore seen to herald the eventual assimilation of Indigenous people into settler society. ${ }^{78}$ As a matter of fact, Woodlands Indigenous beadworkers are known to have protected their cosmologies from the scrutiny of settlers by concealing their sacred signs in floral designs. ${ }^{79}$ For example, the sun and its sacred power, which was traditionally represented by a sequence of colourful, concentric rings of line work, was easily modified to look like a flower head, and it so appears on numerous historical Woodlands Indigenous objects, particularly those made for the tourist trade. ${ }^{80}$

From her apparent enthralment with Indian chintz and its decorative language to her incorporation of the very fabrics that resulted from the appropriation of this foreign textile tradition by the British and their means of production, Morris inadvertently represents the imperial economy that was imposed upon Indigenous people in and around the Hudson's Bay drainage basin starting in the seventeenth century. As we have seen, the trade in Indian chintz and English printed cottons by the East India Company and the Hudson's Bay Company, respectively, were integral to the success of British manufacturing and enabled British settler colonial ambitions in Canada, where fabrics of British manufacture were popular amongst settlers and traded with Indigenous peoples for access to natural resources and land. Indeed, The Dish with One Spoon Wampum Belt Covenant was instituted by the Anishinaabeg and Haudenosaunee First Nations in 1701 precisely because the foreign marketplace had disrupted their environmental and political relationships, and later land agreements would further disorder Indigenous relations by dislocating Indigenous people from their traditional territories. Though north-eastern Woodlands Indigenous people resisted the power politics of imported florals by taking an aesthetic interest in such designs and appropriating them to their own ends, the floral decorative language exemplified by the quilt treasured by the Morris family nevertheless contributed to a visual and material culture that sought to normalise the occupation of Indigenous lands by British authorities and settlers.

\footnotetext{
77 Steve Cotherman, 'Art Traditions of the Anishinaabe Bandolier Bags from the Collection of the Madeline Island Museum', Wisconsin Magazine of History 93, no. 4 (Summer 2010): 30.

78 Phillips, Trading Identities: The Souvenir in Native North American Art from the Northeast, 1700-1900 (Montreal and Kingston: McGill-Queen's University Press, 1998), 175.

79 Lois S. Dubin, Floral Journey: Native North American Beadwork (Los Angeles: Autry Center of the American West, 2014), 67.

80 Phillips, Trading Identities, 195; Dubin, Floral Journey, 67.
} 
This text is taken from International Review of Environmental History, Volume 7 , Issue 1, 2021, edited by James Beattie, Ruth Morgan and Margaret Cook, published 2021 by ANU Press, The Australian National University, Canberra, Australia.

doi.org/10.22459/IREH.07.01.2021.02 